\title{
Integrating genre with ethnography as methodology in understanding L2 writing instruction in a Chinese university
}

\author{
Yimin Zhang ${ }^{1}$ (i) and Issra Pramoolsook ${ }^{2^{*}}$ (1)
}

\author{
*Correspondence: \\ issra@sut.ac.th \\ ${ }^{2}$ School of Foreign \\ Languages, Institute of Social \\ Technology, Suranaree \\ University of Technology, 111, \\ University Avenue, Muang, \\ Nakhon Ratchasima 30000 \\ Thailand \\ Full list of author information \\ is available at the end of the \\ article
}

\begin{abstract}
With a growing recognition of the need to go beyond text and look into the context where the writing (or the teaching/learning of it) takes place, the ethnographic perspective has been fruitfully adopted in academic writing research. The present study, integrating the perspective of genre and ethnography as methodology, probed into the context of L2 English writing instruction in a Chinese university where three writing-related courses were offered to English majors throughout the curriculum. Through a sustained engagement in the courses under focus, we collected multiple types of data, such as the students' writing samples, documents, teaching materials, and semi-structured interviews with students and course instructors, in an attempt to give a rich account of the core participants' real-life experiences in teaching and learning L2 English writing. Results demonstrated that, although informed by the same national syllabus, the L2 writing instruction in reality consisted of a pedagogical "mosaic" that included the traditionalist, process-based and genre-based approaches, as well as various strategies chosen and practiced by individual instructors based on their own theoretical and pedagogical orientations. Future research may explore L2 writing instruction in analogical contexts more extensively through the suggestions offered in this paper.
\end{abstract}

Keywords: Genre, L2 writing instruction, Ethnography as methodology, Chinese context

\section{Introduction}

For most of the time, the principal object of academic writing research has been the written texts. Yet, there is now a growing recognition of the need to go beyond texts and look into the context of writing as well as the teaching/learning of it. Among the various approaches to exploring the complexities of writing context, ethnography has played a primary role. In the existing literature, research taking an ethnographic stance has been richly documented in the areas of postgraduate writing (e.g., Casanave, 2002; Gao, 2012; Paltridge \& Woodrow, 2012; Tardy, 2009) and scholarly writing for publication (e.g., Canagarajah, 2002; Flowerdew, 2000; Hasrati, 2013; Lillis \& Curry, 2010). Paltridge et al. (2016) provide a well-rounded review of such

c) The Author(s) 2022. Open Access This article is licensed under a Creative Commons Attribution 4.0 International License, which permits use, sharing, adaptation, distribution and reproduction in any medium or format, as long as you give appropriate credit to the original author(s) and the source, provide a link to the Creative Commons licence, and indicate if changes were made. The images or other third party material in this article are included in the article's Creative Commons licence, unless indicated otherwise in a credit line to the material. If material is not included in the article's Creative Commons licence and your intended use is not permitted by statutory regulation or exceeds the permitted use, you will need to obtain permission directly from the copyright holder. To view a copy of this licence, visit http:// creativecommons.org/licenses/by/4.0/. 
endeavours, observing that "arguably, we are witnessing an 'ethnographic turn' in academic writing studies" (p. 38). Nevertheless, the ethnographic perspective has been relatively slow in filtering through undergraduate spaces, especially so in the EFL contexts (e.g., Gimenez, 2012; Leki \& Carson, 1997; Starfield, 2004; Tardy, 2015).

In mainland China, research on the undergraduate-level students' L2 writing and writing instruction has also been mostly pursued through textually-oriented lenses (Liardét, 2018; Liu, 2015; Ma, 2009; Qi, 2004; Wang, 2010; Xu, 2010). To our best knowledge, only one study looked ethnographically into undergraduate English writing in the Chinese context (Paltridge, 2007). In an effort to investigate the writing component of College English Tests (CET) Band 4 and Band 6 (two national highstakes English test for Chinese university students), Paltridge (2007) examined sample tests, CET teaching materials, model texts provided in CET textbooks, published curriculum requirements for College English courses and the official CET website, and conducted focus group discussions with College English teachers and semi-structured interviews with test examiners. With these multiple types of data, Paltridge's study offered a situated understanding of the nature and character of CET, pointing to the benefit of going beyond the text and looking for contextual factors impacting student writing. Outside the test venues, however, much less is known about what happens in the authentic writing classrooms for Chinese undergraduate students.

In recent decades, the notion of "genre", a powerful tool in L2 writing as well as in traditional L1 composition studies (Hyland, 2007; Tardy, 2009), has grown in prominence in undergraduate-level writing instruction in EFL contexts. This is particular true in mainland China, where a large population of writing instructors are increasingly called upon to respond to the widely-felt demand for providing undergraduate students with genre-oriented writing support ( $\mathrm{Li}$ et al. 2020). Against this backdrop, the picture of how the element of genre is incorporated by the Chinese writing instructors in their courses remains largely opaque. Thick descriptions of actual classrooms are likely to provide wider implications so as to gauge how the field can be better prepared for meeting this rising demand.

Therefore, in this paper, we shall take up several related questions that are both theoretically and pedagogically motivated. Primarily, we are concerned with the real-life experiences of both students and teachers in the L2 writing classrooms; the specific research questions can be listed as follows:

1. What instructional approaches are adopted by the individual instructors and what assumptions do they hold towards L2 writing that dictate their choice of pedagogies?

2. What kinds of genres are addressed by instructors?

3. How and to what extent does the writing instruction impact upon the students' genre learning?

To probe these questions, we carried out an ethnographic investigation of the undergraduate writing instruction in one Chinese university. Before giving details of our research procedures, we shall first explicate several theoretical and methodological issues pertaining to our subsequent analyses and discussions. 


\section{Theoretical and methodological toolkit}

\section{Approaches to $\mathrm{L} 2$ writing instruction}

Since the inception of L2 writing as a discipline, several pedagogical approaches were proposed and implemented (for a historical review, see Matsuda, 2003). Atkinson (2018) has teased out three major theoretical umbrellas that have framed L2 writing and its evolution: namely, the traditionalist basic skills approach, process approach, and genre-based approach.

Originated in the 1960s, the traditionalist basic skills approach views writing as a body of universally applicable writing skills from letter formation to vocabulary, to sentence grammar, to paragraph organisation, which are merely technical to be acquired. Therefore, students are facilitated by performing decontextualised writing exercises, and the content or meaning is only secondary to formal correctness (Luke \& Freebody, 1997).

Well into the 1970s and 1980s, the interest in L2 writing studies began to shift from the properties of texts to the writing processes (Zamel, 1983; see also Sasaki, 2000). Atkinson (2018) summarised the "core values" of process approach as: "(a) Writing is the discovery of meaning; (b) Writing is a systematic process which can be divided into steps or stages-for example, prewriting, drafting, feedback, revising, and editing; and (c) The development of ideas/content precedes the achievement of correct form" (p. 2).

Afterwards, rising critiques against process approach hastened the advent and development of genre-based approach to L2 writing, resulting in differentiated theories and practices within various contending schools, e.g., Systemic Functional Linguistics (SFL, also known as 'Sydney School'), English for Specific or Academic Purposes (ESP/EAP), New Rhetoric, and Academic Literacies. In practice, SFL and ESP/EAP approaches are the two most influential orientations in L2 classrooms worldwide (Hyland, 2007). In SFL, specifically, genre theorists identified a broad range of key genres that students are required to grasp in various subject areas, namely, stories, chronicles, reports, explanations, procedures, arguments, and text responses (e.g., Martin \& Rose, 2008; Rose, 2010). Giving explicit instructions on the social purposes, rhetorical stages, and linguistic features of these genres, teachers can empower students to produce ideally, well-formed texts appropriate to intended modes and readers (Hyland, 2007). This kind of explicit scaffolding, or teacher-supported learning, is developed into a genre-based teaching/ learning cycle featuring three main stages: Deconstruction, Joint Construction, and Independent Construction (Berg \& Leonidova, 2021; Martin \& Rose, 2005, 2007; Rothery \& Stenglin, 1994). ESP/EAP teachers, on the other hand, are more concerned with the communicative needs of particular academic and professional groups and stress the importance of the situatedness of genres in particular contexts which are realised through a series of moves and steps (Bhatia, 1993; Swales, 2004).

\section{Ethnography as methodology}

As a research methodology originated in anthropology and sociology in the late nineteenth century, ethnography is open-ended and diverse in nature. Lillis (2008) has articulated its potential value to academic writing research at three different levels: ethnography as method, ethnography as methodology, and ethnography as deep theorising. 
At the minimal level, ethnography as method relies on text-based interviews, or "talk around texts", as a supplementary method to directs the researcher's attention from the written texts to the writers' perspectives about specific texts or some wider issues about writing. Although this method has been commonly used in academic writing research, limited forms of talk around texts may only provide "minimal glimpses of writers' perspectives and understandings” (Lillis, 2008, p. 361).

At the second level, ethnography as methodology essentially embodies two core values of ethnography to distinguish itself as methodology rather than as method: (a) lengthy or sustained engagement in participants' academic writing worlds, and (b) collection and analysis of multiple types of data in order to build holistic understandings. In this way, this approach ensures a thick participation and a thick description (Sarangi, 2006), enabling the researchers to explore and track "the dynamic and complex situated meanings and practices that are constituted in and by the writing" (Lillis, 2008, p. 355).

At the third, and the most abstract, level, ethnography as deep theorising engages more thoroughly with the social, cultural, historical, and political dimensions of the contexts in which the texts are produced and consumed (Paltridge et al., 2016). Understanding texts as illuminating social and cultural practices, ethnography as deep theorising can be usefully applied to narrow "the ontological gap" between language and culture, text and context (Lillis, 2008).

In the present study, ethnography as methodology is deemed as appropriate to pursue the aforementioned research questions. By synergising the perspective of genre with our ethnographic investigation, we aim to provide a thick description of the teaching and learning of L2 English writing at the undergraduate level in the Chinese context, and more specifically, to what extent and through which means the element of genre is incorporated in the writing instruction.

\section{This study}

\section{Research scenario}

This study was carried out in the English Department in a public university in Southwestern China. Students in this Department take general writing courses in the first semester (English Writing I, EW I) and second semester (English Writing II, EW II) in the second year. In the second semester of Year 3, the students take a 10-week course of Academic Writing (AW), which offers an introduction to MLA writing conventions and prepares students for the forthcoming bachelor's thesis writing.

Due to the limited time span, we explored cross-sectionally, instead of longitudinally, the students' and teachers' experiences in the three writing-related courses. In the Spring of 2018, we concurrently engaged in and collected data from AW and EW II when they were offered to students enrolled in the academic years 2015 and 2016; and in the Autumn of 2018, we moved to EW I with students enrolled in 2017. At the time of research, four teachers worked jointly in EW I \& II and another full professor was in charge of AW.

Prior to the data collection, we requested official approval from the institute's administrators to access the Department. All the student/teacher-participants signed an informed consent form. They were assured that their participation was on a voluntary basis and that no interests nor potential risks were associated with their participation 
or non-participation in the research. To protect their confidentiality, names used in this paper are pseudonyms.

\section{Data sources and data collection}

In compliance with ethnography as methodology, we observed the three writing courses under focus through a sustained engagement, pulling together data from multiple sources.

To begin with, we collected the full package of in- and out-of-class written assignments from 40 students in each of the three courses, creating a small corpus containing a total of 611 written assignments. Textual analysis of this small corpus based on SFL genre theories has been reported elsewhere (Zhang \& Pramoolsook, 2020). In this paper, our focus is on the contextual aspects of the writing instruction. As such, the ethnographic data illuminating the context came from the following three major sources:

First, we scrutinised the national syllabus for tertiary English education in China, an official document that mirrors the higher-level expectations from the policymakers. Second, we collected the teaching materials designed and used by the individual instructors, including the textbooks, PowerPoint slides, and model texts. We assume that these firsthand teaching materials provided a window to probe into the ways the course instructors organised their lessons.

In addition, semi-structured interviews were conducted with students and focal course instructors. Of the four teachers involved in EW I \& II, two of them did not respond to our request for recorded interviews, and the other two were interviewed twice, once at the end of EW I and once at the end of EW II. The professor in AW was interviewed once at the end of his course. Meanwhile, for each course, we invited and interviewed five students from those who contributed their assignments to our corpus. The selected interviewees were basically active learners in the courses, who are articulate, expressive, and reflective on their writing-related learning experiences. Among the 15 student interviewees, six are males and nine females.

In keeping with our research purposes, a list of open-ended questions was prepared and sent to three experts in the field of L2 writing research for content validity evaluation. The interview questions were refined where necessary based on the experts' feedback. The actual interview questions being asked are presented in the Appendices. The interviews were conducted in the native language of the informants. Each interview lasted about 20-35 min and was audio-recorded.

\section{Data analysis}

The focus of our analysis was not on the effectiveness of the writing instruction being offered, but on making sense of the pedagogical practices as shaped by the multi-layered contexts (the national, institutional, as well as the local classroom scenarios). All the ethnographic data were subject to analysis based on thematic coding, combining categorising and connecting strategies (Maxwell, 2005).

In the first step, we examined the sections concerning writing in the national syllabus and noted mentions of genre(s) that the students are expected to acquire at different stages in university. This allowed us to acquire some understanding of the broad discoursal, or generic, aspirations at the national level. 
For unknown reasons, the textbooks designated by the Department for the three writing courses were not used at all either by the instructors or by the students, so they were excluded from our analysis. As we looked through the other teaching materials, it soon became clear that the teaching of the individual instructors demonstrated distinct features of certain instructional approach(es). Therefore, the instructors' PowerPoint slides were coded with the major approaches they implemented as the higher-level codes, which subsumed lower-level in vivo codes based on the section headings they used in their slides. These in vivo codes further subsumed lower-level codes which gathered evidences that embodied elements central to their implemented approaches. Since two of the instructors in EW I \& II observably incorporated the concept of genre in certain parts of their teaching agenda, illustrative pieces of data in their relevant slides were annotated with particular genres being addressed following the SFL genre categorisation. As another connecting strategy of analysis, we also labelled the genres in the model texts used by the instructors. In AW, a more research-oriented writing course, the instructor manifested some salient traits characteristic of the EAP approach. Drawing on Tribble's (2002) framework of academic writer knowledge, an analysis of his teaching contents was conducted to explore the types of writing knowledge addressed in this course.

In the next step, we transcribed and translated all the interview recordings and annotated the transcripts for relevant and meaningful chunks that brought out deeper insights into the codes generated from the on-going analysis. We kept the codes on the individual instructors distinct from each other, to maintain the logic and connection of the within-case stories, while constantly making cross-case comparisons to look for similarities and differences in their ways of teaching.

As a way of member checking, the interviewees were asked to read the (translated) transcripts of the interviews they participated in, to make sure that the words did match what they intended. To promote the reliability of our analysis, frequent debriefing sessions were held between the first author of this paper and the second author who was responsible for this study in a more supervisory capacity. As a way of cross-checking, the ethnographic data were first analysed by the first author, alternative approaches to interpreting the data were discussed during the debriefing sessions, and ultimately, the codes and themes were agreed upon by both authors.

To recapitulate, our analysis led us to decide that characterising the distinguishing features of the focal teachers' instruction and delineating the way their teaching impacted the students' learning of writing and their awareness towards genre would effectively bring out the themes that best address our research questions. In what follows, we shall give a situated account of the current instructional context. Specifically, we first explicate the generic aspirations at the national level, and then, by creating narratives from the other qualitative data (chiefly teaching materials and interviews), build up a profile for the four focal instructors in the three writing courses. One instructor was excluded, because he declined our interview request and provided only a limited portion of his teaching materials. So, we did not acquire enough data to reconstruct his story. The demographic data of the four instructors are given in Table 1. 
Table 1 Demographic data of the focal instructors

\begin{tabular}{llllll}
\hline Pseudonyms & Gender & Nationality & Degree & Professional title & Years of teaching EFL writing \\
\hline Lin & Male & Chinese & Bachelor & Associate professor & More than five years \\
Cheng & Female & Chinese & Master & Lecturer & Four years \\
Michelle & Female & American & Master & Lecturer & One year \\
Wang & Male & Chinese & Master & Professor & More than five years
\end{tabular}

\begin{tabular}{|c|c|c|c|}
\hline Year 1 & Year 2 & Year 3 & Year 4 \\
\hline $\begin{array}{l}\text { - Be able to } \\
\text { write a short } \\
\text { essay of } \\
120-150 \\
\text { words within } \\
30 \text { min } \\
\text { - Be able to } \\
\text { write } \\
\text { practical } \\
\text { genres, e.g., } \\
\text { notes and } \\
\text { notices }\end{array}$ & $\begin{array}{l}\text { Be able to write } \\
\text { a short essay of } \\
\text { about } 150-200 \\
\text { words within } 30 \\
\text { min, according to } \\
\text { a given topic, } \\
\text { outline, } \\
\text { diagramme, or } \\
\text { data } \\
\text { - Be able to write } \\
\text { a practical genre } \\
\text { of about } 60 \\
\text { words within } 10 \\
\text { min }\end{array}$ & $\begin{array}{l}\text { Be able to write } \\
\text { story synopses, } \\
\text { book reports, } \\
\text { course papers, } \\
\text { and formal } \\
\text { correspondences } \\
\text { - Be able to write } \\
250-300 \text { words } \\
\text { in } 30 \text { min }\end{array}$ & $\begin{array}{l}\text { Be able to write } \\
\text { all kinds of } \\
\text { genres } \\
\text { - Be able to write } \\
300-400 \text { words } \\
\text { in } 30 \text { min } \\
\text { - Be able to write } \\
\text { a bachelor's } \\
\text { thesis of } 3000 \text { - } \\
5000 \text { words }\end{array}$ \\
\hline
\end{tabular}

\section{Findings: a situated account}

\section{Generic aspirations in the national syllabus}

The national syllabus has orchestrated the overall undergraduate English education in Chinese universities. Regarding writing, it is stated that English writing courses aim at “training students' fundamental English writing abilities, including the abilities to write outlines, summaries, short essays as well as simple practical writing" (2000, p. 15). More specifically, it emphasises an accumulation of knowledge from words and sentence structures, to paragraph writing strategies, to textual structure and organisation, to writing short essays. When it comes to genre, the national syllabus states:

If conditions permit, students should be further trained to master all kinds of genres and their textual structures, such as the descriptive, narrative, expository and argumentative. (p. 16)

Obviously, the ability to write different genres is placed at a relatively advanced level. However, the term "genre" concept is somewhat loosely categorised, linked to the broad types of writing or common rhetorical modes (i.e., descriptive, narrative, expository and argumentative). On the basis of that, the national syllabus sets forth more specific learning outcomes expected from students going through the four-year programme. For a quick review, these learning outcomes are reproduced diagrammatically in Fig. 1, with italics placed on the types of genres being emphasised.

As seen in Fig. 1, students should be able to write some basic genres at different levels of study, e.g., story synopses and book reports (text responses in SFL terms), together with some practical genres, before the culminating bachelor's thesis. Beyond that, the term 
"short essay" has been used as an umbrella term throughout the syllabus, with no specifications on what genre it is actually realising, which makes it hard to envision how students are supposed to gain a holistic grasp over "all kinds of genres" in the final year. To better understand how the somehow ambiguous aspirations in the national syllabus have been translated into concrete pedagogical practices, it is necessary to probe into what the writing teachers think and actually do in the local classrooms and how their teaching is received by and impacts the students.

\section{Instructor's approaches to teaching writing: a pedagogic "mosaic"}

Individual writing teachers came into their classrooms with diverse backgrounds of education, disciplinary expertise, and experiences in L2 writing instruction. They enjoyed much freedom in choosing their materials and strategies in teaching, despite the same national syllabus to cover. Consequently, the actual pedagogic site, metaphorically, resembled a "mosaic". To present a clearer picture of this "mosaic", we shall zoom in on the individual teachers, building up their instructional profile by drawing on teaching materials they developed and used for the related courses and the interview data from both teachers and students involved. In the following narratives we created for the four focal instructors, italics is applied on the reoccurring in vivo subthemes.

\section{Professor Lin: a traditionalist}

Professor Lin is a senior faculty member in the Department. He holds a bachelor's degree in English language studies and had been teaching writing in this Department for more than five years. Throughout his sessions in the two writing courses, he struck us as an enthusiastic proponent of the traditionalist basic-skills approach. The 298 PowerPoint slides he designed and used in the courses covered chiefly three themes, namely, useful sentence patterns, language revision, and nominalisation, showcasing a preponderant focus on the formal elements of language at the word-, sentence- and paragraph- levels.

Table 2 Overview of Professor Lin's teaching contents

\begin{tabular}{|c|c|c|c|}
\hline Theme & Sub-theme & Level & NO. of slides \\
\hline \multirow[t]{5}{*}{ I. Useful sentence patterns } & Sentence patterns used in introductions & Sentence & 54 \\
\hline & Sentence patterns used in conclusions & Sentence & 48 \\
\hline & $\begin{array}{l}\text { Sentence patterns used to explain causes } \\
\text { \& effects }\end{array}$ & Sentence & 20 \\
\hline & $\begin{array}{l}\text { Sentence patterns used for comparison \& } \\
\text { contrast, pros \& cons }\end{array}$ & Sentence & 9 \\
\hline & Substituting with richer choices of words & Word/sentence & 56 \\
\hline \multirow{7}{*}{$\begin{array}{l}\text { II. Language revision of } \\
\text { problematic uses }\end{array}$} & Insufficient supporting details & Paragraph & 8 \\
\hline & Repletion \& redundancy & Paragraph & 16 \\
\hline & Unparalleled sentence structure & Sentence & 10 \\
\hline & $\begin{array}{l}\text { Improper use of transitional words and } \\
\text { cohesive devises }\end{array}$ & Sentence/paragraph & 24 \\
\hline & Erroneous logic in sentences & Sentence & 14 \\
\hline & Ambiguous $S+V$ structure & Sentence & 6 \\
\hline & Punctuation & Orthography/sentence & 6 \\
\hline III. Nominalisation & Word & 27 & \\
\hline
\end{tabular}


To present a more quantifiable picture of his deep entrenchment in the basic skills, Table 2 summarises the major contents in his presentation slides with the number of slides devoted to each theme/subtheme.

In illustrating each subtheme, Professor Lin frequently used model texts in the class but most of them were disconnected and decontextualised. His preoccupation with basic skills was also evident in the two interviews we carried out with him, during which the terms "sentence structure" or "sentence pattern" constantly resounded. In the endof-EW-I interview, for example, he described the primary objective of English Writing courses as "how to think in English", but the logic of English, in his conception, lied entirely in the basic subject + verb + object construction within a sentence.

I raised the question to my students in the first class 'what is the logic of English?', just to show them that the logic of English is embodied in the very basic structure of a sentence, that is, subject + verb + object. (Professor Lin, interview, EWI)

In the end-of-EW-II interview, Professor Lin continued to express his expectations for students to write "clearly, idiomatically and logically", which, in his idea of "good writing", was narrowly related to "appropriate choice of words, sentences, and contents".

Regretfully, however, focusing solely on the sentence-level exercises seemed demotivating to the students in the class, causing unnecessary misunderstanding and a sense of confusion. Feng, one of his students in EW I, admitted that he "never had any experience with formal, standard genres" in the classroom; and when asked whether or not he thought the concept of genre was important to learning English writing, he mumbled "I don't know" with a disconcerting look in his eyes. Another student, Mei, reflecting on her experiences in Professor Lin's classes, launched a more direct complaint in the interview:

To be honest, I don't know what he was teaching. It was too messy. He assigned some exercises, but I had no clue what they were for. I did not see the relevance. Sometimes I just could not get his point. When he presented us a very long example in the class, it did not actually make much sense to me. (Mei, EW I, interview)

\section{Ms Cheng: deep involvement with genre-based pedagogy}

Ms Cheng is a young Chinese-L1 lecturer in the Department, holding a master's degree in linguistics and applied linguistics. Her approach to teaching writing was recognisably influenced by the genre-based pedagogy. She started EW I with a general introduction to the four broad types of genres, or "rhetorical modes" in her own terms (narration, description, exposition, argumentation), as well as several issues related to the proper use of punctuations and stylistics behind word choice. In the opening of EW II, she illuminated how to develop an effective, focused topic sentence and then a coherent paragraph. For the remaining class hours, she organised her teaching around the four rhetorical modes, moving gradually from narration and description in EW I to exposition and argumentation in EW II. Though she did not strictly follow the SFL nomenclature, she constantly encouraged the students' active participation in a variety of key written genres that could be associated with this school. Essentials of her instructional contents in the two courses were summarised in Tables 3 and 4. 
Table 3 Overview of Ms Cheng's teaching contents in EW I

\begin{tabular}{|c|c|c|c|}
\hline Theme & No. of slides & Details & Genres involved \\
\hline Introduction & 10 & $\begin{array}{l}\text { orientation \& course requirements; } \\
\text { four common rhetorical modes } \\
\text { (narration, description, exposition, } \\
\text { argumentation) }\end{array}$ & \\
\hline Punctuation & 20 & & \\
\hline Proper words & 21 & $\begin{array}{l}\text { words \& style: informal v.s. formal; } \\
\text { practical v.s. eloquent; general v.s. } \\
\text { specific }\end{array}$ & \\
\hline Narration & & to entertain & \\
\hline Personal narratives & 5 & $\begin{array}{l}\text { chronological order; insights into } \\
\text { human behaviour or motivation }\end{array}$ & recount, exemplum \\
\hline Objective reports & 6 & attitudes/feelings & anecdote \\
\hline Unpleasant experiences & 6 & $\begin{array}{l}\text { showing or telling; chronological } \\
\text { order; use of action verbs }\end{array}$ & narrative, observation \\
\hline Historical narratives & 3 & $\begin{array}{l}\text { a person's life; history of a family; } \\
\text { establishment and development } \\
\text { of an organisation; [introduction } \wedge \\
\text { account } \wedge \text { remark] (c.f., Orientation } \\
\wedge \text { Life Stages/Sequence of Recount } \wedge \\
\text { Deduction) }\end{array}$ & $\begin{array}{l}\text { biographical recount, historical } \\
\text { recount }\end{array}$ \\
\hline \multicolumn{4}{|l|}{ Description } \\
\hline Place & 6 & $\begin{array}{l}\text { senses; spatial order; features; a } \\
\text { dominant expression }\end{array}$ & descriptive report, anecdote \\
\hline Object & 3 & $\begin{array}{l}\text { senses; spatial order; } \\
\text { features/functions; a dominant } \\
\text { expression }\end{array}$ & \\
\hline Person & 6 & $\begin{array}{l}\text { personality; behaviour; qualities; con- } \\
\text { crete, vivid details; person in action; } \\
\text { using anecdotes }\end{array}$ & \\
\hline
\end{tabular}

Table 4 Overview of Ms Cheng's teaching contents in EW II

\begin{tabular}{|c|c|c|c|}
\hline Theme & NO. of slides & Details & Genres involved \\
\hline Topic sentence & 13 & $\begin{array}{l}\text { characteristics: focused, manage- } \\
\text { able, discussable, interesting; } \\
\text { placement }\end{array}$ & exposition, descriptive report \\
\hline Paragraph development & 12 & $\begin{array}{l}\text { unity; coherence; ordering of } \\
\text { information }\end{array}$ & $\begin{array}{l}\text { observation, recount, descriptive } \\
\text { report, sequential explanation, } \\
\text { factorial explanation, }\end{array}$ \\
\hline Exposition & & To convey information or explain & \\
\hline Exemplification & 5 & choose appropriate examples & exposition \\
\hline Process analysis & 5 & $\begin{array}{l}\text { step-by-step process of how to do } \\
\text { things; how something is donel } \\
\text { made; how something happened }\end{array}$ & $\begin{array}{l}\text { procedure, procedural recount, } \\
\text { autobiographical recount }\end{array}$ \\
\hline Cause-effect analysis & 6 & $\begin{array}{l}\text { [background/phenomenon } \wedge \\
\text { cause } 1,2,3 \ldots \text { /effects } 1,2,3 \ldots \wedge \\
\text { restatement] (c.f., Phenomenon } \wedge \\
\text { Factor } 1,2,3 \ldots / \text { Consequence } 1,2, \\
3 \ldots \wedge \text { Deduction) }\end{array}$ & $\begin{array}{l}\text { factorial explanation, consequential } \\
\text { explanation }\end{array}$ \\
\hline Argumentation & 19 & $\begin{array}{l}\text { to persuade; four core elements: } \\
\text { issue, claim, support, refutation; } \\
\text { from more than one side }\end{array}$ & exposition, discussion, challenge \\
\hline
\end{tabular}


Ms Cheng's commitment to genre could also be observed from her many other instructional behaviours. For example, she relied considerably on scaffolding in her classroom practices, which typically unfolded through [Deconstruction ${ }^{\wedge}$ Joint Construction $\wedge$ Independent Construction] in the SFL teaching/learning circle. In the Deconstruction stage, she adopted two teaching methods, "concept explanation" and "sample analysis", to make explicit to students the social purposes, core features, and rhetorical structures of the genres in focus. For sample analysis, she used 23 model texts covering a wide range of genres: two recounts, one anecdote, two observations, two narratives, one historical recount, one autobiographical recount, six descriptive reports, one sequential explanation, one factorial explanation, one procedure, four expositions, and one discussion. Another teaching method she called "writing practice" included Joint Construction of target genres in class and Independent Construction by the students themselves after class. A snapshot of one slide Ms Cheng presented in Introduction session of EW I (Fig. 2) provides a quick, yet only partial, window to her principled adherence to genre-based pedagogy.

Unsurprisingly, students in Ms Cheng's classes exhibited a heightened awareness towards genre (or genres) in the interview data:

It (the knowledge of genre) is very important. We just learnt two types this term, the narrative and descriptive. In general, when we write, we must know what our purpose is. For different purposes, we use different genres, different language, and different structures. (Wei, EW I, interview)

I think whatever we write, we have a potential audience. We should be clear who they are. In order to attract their attention, we need to find out the most effective ways to express ourselves. The concept of genre provides such a weapon, like writing models, to attract the audience. (Anling, EW I, interview)

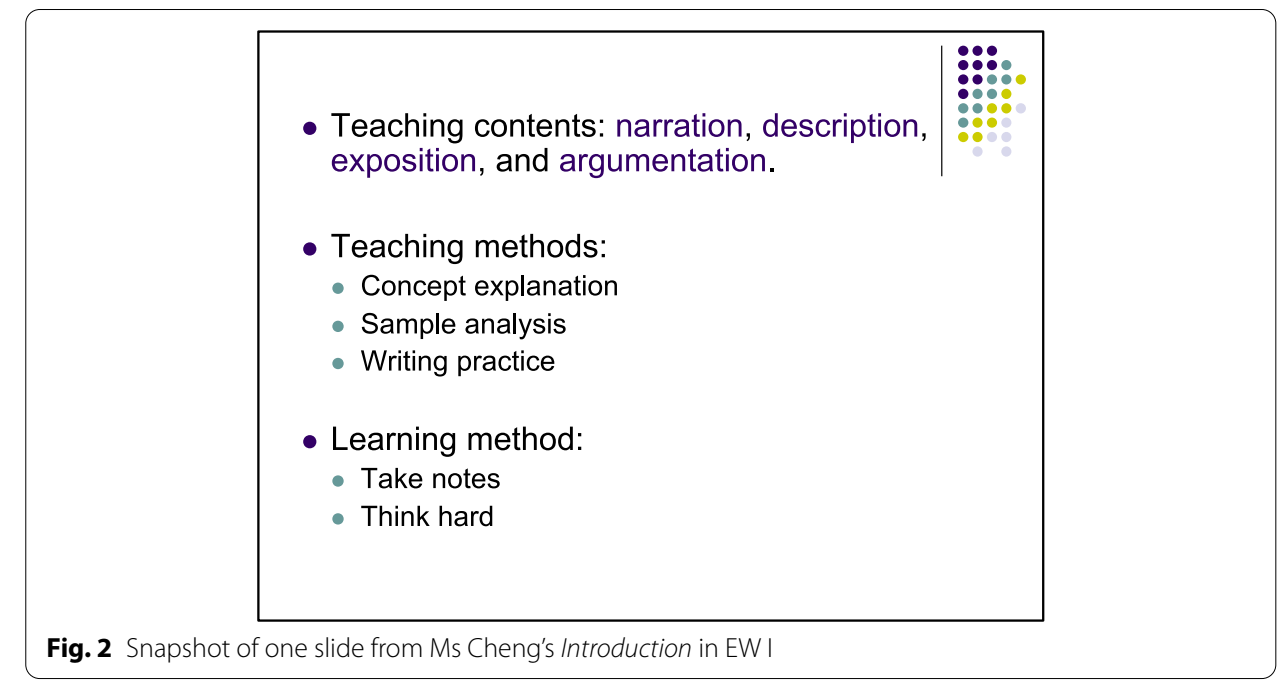


Table 5 Overview of Ms Michelle's arrangement in EW I

\begin{tabular}{|c|c|c|}
\hline Theme & Sub-theme & NO. of slides \\
\hline Orientation & $\begin{array}{l}\text { types of writing overview: narrative, descriptive, expository, persuasive/argumenta- } \\
\text { tive; different parts of an essay; professional emails; résumés }\end{array}$ & 16 \\
\hline Introduction & hook; thesis statement & 10 \\
\hline Body & $\begin{array}{l}\text { building on the claims stated in the thesis statement; applicable to any type of } \\
\text { writing; using details instead of claims if doing more of a narrative style }\end{array}$ & 16 \\
\hline Conclusions & restate opinion; look towards the future; ask questions & 10 \\
\hline Emails & $\begin{array}{l}\text { purposes: to complain, inform, advertise, apologise, etc.; tone: informal, neutral, } \\
\text { formal }\end{array}$ & 21 \\
\hline Résumés & layout and key components & 27 \\
\hline
\end{tabular}

Table 6 Overview of Ms Michelle's teaching contents in EW II

\begin{tabular}{|c|c|c|c|}
\hline Theme & NO. of slides & Sub-theme & Genres involved \\
\hline Orientation & 10 & $\begin{array}{l}\text { review of four types of writing: narrative, descriptive, } \\
\text { expository, persuasive/argumentative; }\end{array}$ & \\
\hline Descriptive writing & 11 & five senses; picture in mind & descriptive report \\
\hline Expository writing & 18 & $\begin{array}{l}\text { to explain; not giving opinions; daily-life writing; focused } \\
\text { only on "how-to articles" }\end{array}$ & procedure \\
\hline Narrative writing & 14 & $\begin{array}{l}\text { [title } \wedge \text { setting } \wedge \text { characters } \wedge \text { problem } \wedge \text { complicate the } \\
\text { problem } \wedge \text { resolve the problem] }\end{array}$ & narrative \\
\hline $\begin{array}{l}\text { Persuasive/argu- } \\
\text { mentative writing }\end{array}$ & 19 & $\begin{array}{l}\text { OREO: [opinion } \wedge \text { reason } \wedge \text { evidence } \wedge \text { opinion restated]; } \\
\text { five-paragraph structure }\end{array}$ & exposition, \\
\hline
\end{tabular}

\section{Ms Michelle: incorporating genre and process}

Ms Michelle, a Peace Corps volunteer from the U.S., holds a master's degree in Education and came to teach in this university on a 2-year service. A suitable description of her instructional approach in the two fundamental writing courses was that she conceivably adopted an eclectic approach, with her foot set in two of the pedagogical camps: one in genre and the other in process.

The genre side. In the opening class of EW I, Ms Michelle provided an overview of the four "types of writing", i.e., narrative, descriptive, expository, and persuasive/argumentative. She then stated that her two foci in this course were how to write different parts of an essay, namely, introduction, body, and conclusion, and a brief introduction to professional emails and résumés in the final two weeks. Table 5 summarises the focal points of Ms Michelle's teaching contents in this course.

At this stage, genre was not yet a priority on Ms Michelle's teaching agenda. She did not go any further into the specific types of writing, but instead developed her lessons around how to write an "essay", an umbrella term used throughout the course. Then, on the occasion of the Peace Corps $25^{\text {th }}$ Anniversary Writing Competition, she guided the students to write a short essay on the topic "Volunteer! Make a Difference!", adhering to the format of "five paragraphs" (c.f., Bacha, 2010) consisting of an introductory paragraph of the topic and the statement of a claim, three supporting paragraphs for the claim, and a concluding paragraph.

Moving into EW II, Ms Michelle's attention to genre(s) was noticeably intensified. During this course, she elaborated on the communicative functions, writing strategies, 
as well as rhetorical structures typical of the four types of writing (descriptive, expository, narrative and persuasive). Table 6 summarises Ms Michelle's key points in EW II and their association with genres in the SFL tradition.

Despite the distinctions drawn between different genres, Ms Michelle held an unbiased, neutral attitude towards their relative values in the students' overall development of writing capacity, viewing them of equal importance. For instance, when commenting on the students' work on the topic "Volunteer! Make a Difference!", which seemed to prompt what was more of an augmentative essay than of anything else, she asserted that she was open and would welcome any pieces of writing that fell out of the argumentative bound.

For students in university, I feel like they do write more argumentative essays, because a lot of people want to get their opinions, but I think it is still important to teach the different types. I had some students who were obviously natural storytellers. I think the students really could find I might not be that good at argumentative paper, but I am really good at telling a story', so that they could develop that through what they like. It is important to focus on what they are interested in - anything. (Ms Michelle, interview, EW I)

In the interview at the end of EW II, she further contended that the students' choice of genres was entirely determined by their own purposes in writing:

I think it depends really on what the students want to write, because the students all have different purposes in writing. So, I think it is important to teach, or to have, these different types of writing. (Ms Michelle, interview, EW II)

The process side. Beyond the sphere of genre-based teaching, Ms Michelle also incorporated many strategies of a process approach. These strategies included peer/teacher feedback, production of multiple drafts, less attention to grammar, and extra creative writing activities.

Peer/teacher feedback and multiple drafts. Throughout EW I and II, Ms Michelle required students to trade their paragraphs with one another for peer feedback before offering her own comments. Then, the students should revise and re-edit their paragraphs based on the feedback both from the peers and from the teacher. In this way, the students were actively involved in producing multiple drafts for every writing task and were requested to compile all their drafts into a portfolio, which she called "class journals", to be submitted at the end of the courses. Figure 3 shows a snapshot of a slide that Ms Michelle presented to mobilise the students into giving and receiving peer feedback.

Less attention to grammar. As shown in Fig. 3, in practicing peer feedback, the students were constantly reminded to focus more on the content rather than on the grammar. Such a principle was consistently practiced by Ms Michelle herself in assessing the students' work and later reaffirmed in the interview data.

I don't think I should grade based on grammar or sentence structure. That's not what I teach. Since structure is what I focus on in class, that is what I really focus my comments on. (Ms Michelle, interview, EWI)

I focus more on the content of that essay, not as much on the grammar. (Ms Michelle, interview, EW II) 


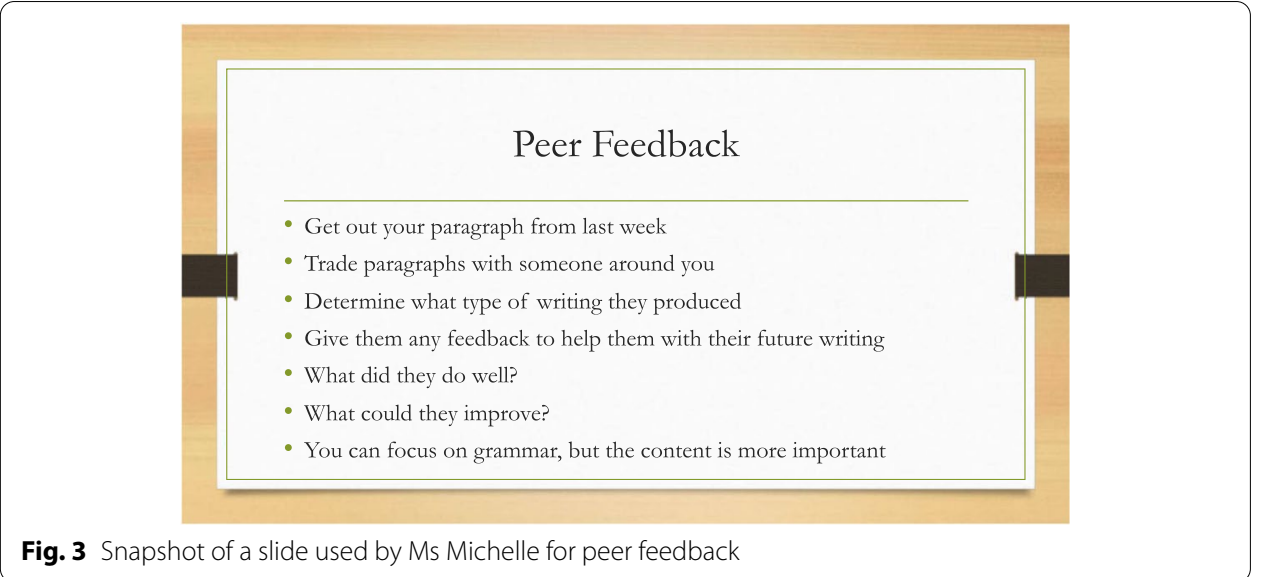

Table 7 What academic writers need to know (Tribble, 2002, p. 131)

\begin{tabular}{ll}
\hline Content knowledge & knowledge of the concepts involved in the subject area \\
\hline $\begin{array}{l}\text { Writing process knowledge } \\
\text { Context knowledge }\end{array}$ & $\begin{array}{l}\text { knowledge of the most appropriate way of carrying out a specific writing task } \\
\text { knowledge of the social context in which the text will be read, and co-texts } \\
\text { related to the writing task in hand } \\
\text { knowledge of those aspects of the language system necessary for the com- } \\
\text { pletion of the task }\end{array}$ \\
\hline
\end{tabular}

Creative writing activities. Extra activities of creative writing were inserted by Ms Michelle into different sessions, such as " 2 truths and 1 lie - getting to know you", "brainstorming", "pass the story - a Halloween scary story", "write, pass and draw", and "oneword group story". The purpose of these creative writing activities was certainly not as much to invite structurally and logically sound texts as to stimulate the flow of creative ideas and to facilitate students' expressiveness and fluency in writing by "just keep writing" (Ms Michelle, interview).

\section{Professor Wang: English-for-Academic-Purposes (EAP) genre approach}

Different from EW I and II, AW was more research-orientated and served a more immediate need to prepare students for the bachelor's thesis - an advanced academic genre that the students were required to accomplish in the final year of their study. In this course, the teaching and learning of the basic genres seemed to have stepped down from the instructional platforms, and salient traits characteristic of the English for Academic Purposes tradition (Bhatia, 1993; Swales, 2004) were observed in Professor Wang's instructional behaviours.

To better understand Professor Wang's teaching foci and his underlying pedagogical values, Tribble's (2002) discussion of academic writer knowledge provided a suitable framework. Specifically, Tribble (2002) identified four categories of knowledge that writers need in order to produce appropriate and effectives texts in specific academic domains, reproduced in Table 7 .

Our analysis of Professor Wang's presentation slides based on this framework was presented in Table 8. To figure out how the four facets of knowledge intersected in this local classroom, the numbers of slides were calculated to index Professor Wang's pedagogical 
Table 8 Overview of Professor Wang's teaching contents in AW

\begin{tabular}{|c|c|c|c|}
\hline Theme & Details & NO. of slides & Domain of knowledge \\
\hline \multirow{5}{*}{$\begin{array}{l}\text { Part One } \\
\text { Introduction }\end{array}$} & Explanation of basic terms & 10 & Content \\
\hline & $\begin{array}{l}\text { Characteristics of academic writing: } \\
\text { objectivity, clarity, coherence, accuracy, } \\
\text { plainness and preciseness }\end{array}$ & 16 & Language system \\
\hline & $\begin{array}{l}\text { Linguistic features of academic writing: } \\
\text { lexical and syntactic }\end{array}$ & 16 & Language system \\
\hline & $\begin{array}{l}\text { Language style of academic writing: ten- } \\
\text { tative, formal, objective, concise, varied }\end{array}$ & 40 & Language system \\
\hline & Procedures of academic writing & 4 & Writing process \\
\hline \multirow{3}{*}{$\begin{array}{l}\text { Part Two } \\
\text { Selecting a Topic \& Devel- } \\
\text { oping Research Questions }\end{array}$} & Principles of topic selection & 48 & Content \\
\hline & $\begin{array}{l}\text { Title writing: purposes, format, and } \\
\text { standards }\end{array}$ & 19 & Context \\
\hline & $\begin{array}{l}\text { Procedures of developing research ques- } \\
\text { tions }\end{array}$ & 34 & Writing process \\
\hline \multirow{3}{*}{$\begin{array}{l}\text { Part Three } \\
\text { Writing a Research Proposal }\end{array}$} & Components of a research proposal & 2 & Writing process \\
\hline & MLA format of bibliography & 26 & Writing process \\
\hline & Boiling down key words & 5 & Writing process \\
\hline \multirow{4}{*}{$\begin{array}{l}\text { Part Four } \\
\text { Writing an Outline }\end{array}$} & Functions of outline & 2 & Context \\
\hline & Process of writing an outline & 2 & Writing process \\
\hline & $\begin{array}{l}\text { Four main components of an effective } \\
\text { outline }\end{array}$ & 4 & Language system \\
\hline & Types of outline & 6 & Writing process \\
\hline \multirow{5}{*}{$\begin{array}{l}\text { Part Five } \\
\text { Abstract Writing }\end{array}$} & Importance of abstract & 7 & Context \\
\hline & Structure of an abstract & 8 & Language system \\
\hline & Types of abstract & 19 & Writing process \\
\hline & Qualities of a good abstract & 2 & Language system \\
\hline & Steps of writing an effective abstract & 3 & Writing process \\
\hline
\end{tabular}

investments in each domain. Out of the total 273 slides, a majority of 101 slides (37.0\%) were related to writing processes (e.g., the procedure of writing an outline or an abstract), and 86 slides (31.5\%) to language system (e.g., the language style of academic writing, structure and linguistic features of abstract). By contrast, content and context were relatively less attended to by the instructor, taking up 58 slides (21.2\%) and 28 slides (10.3\%), respectively -- the former concerning the selection of a researchable topic within the discipline and the latter the communicative purposes of different parts of a bachelor's thesis.

Although this course was not SFL-genre-oriented, Professor Wang, in the interview conducted at the end of the course, reasserted the importance of genre knowledge in developing academic writing competence and gave primacy to arguments in writing a research paper or a bachelor's thesis:

In academic writing, or the bachelor's thesis, it is arguments that do the job. The most important thing is how to make the central argument more powerful and more persuasive. (Professor Wang, interview, AW) 


\section{Discussion}

Probing into the environment of L2 English writing in a Chinese university, our study represents an integrated endeavour marrying the strengths of genre and ethnography as methodology to close the gap between text and context in academic writing research. At the outermost, conditioned by the provisions in the national syllabus for English major undergraduates, the teaching and learning of L2 English writing were crystallised in varied manners by individual instructors in the local classrooms. In the current scenario, the principles and practices of basic skills, process, SFL- and EAP-based genre approaches were all simultaneously implemented and thoughtfully combined, with the notion of genre being addressed to varying degrees.

Although our focus in this study was not on the efficacy of the focal teaching and students' learning, our findings did show that the judicious combination of strategies and approaches aroused different feedback from the recipients. Professor Lin's traditionalist approach, with a single-minded focus on some basic language knowledge, seemed to be less well-received by the student writers. Although formal knowledge at word, sentence, and paragraph levels is called for in the Chinese national syllabus, the disconnected and decontextualised lexical-grammatical activities seemed unlikely to promote the students' overall writing capacity. Despite of that, formal language instruction should not be rendered unnecessary, especially for L2 learners who are still facing a challenging, long-term process of L2 acquisition. To offset the unfavourable effects that focusing on language forms riskily entails, it is probably most optimal for the writing teachers to mindfully integrate the formal language instruction with analysis on other important dimensions of writing, such as communicative purposes, genres, and their unfolding structures, so that word/sentence-level instruction in writing classrooms could be brief, narrowly-focused and authentically integrated with the rhetorical settings (Ferris, 2017).

The other two instructors, Ms Cheng and Ms Michelle, manifested some overlapping characteristics in accommodating genre in their teaching practices. To some extent, their choice and arrangement of genres echoed the generic aspirations set up in the national syllabus, which helped them narrow the vast universe of meaning to a manageable and reasonable set of priorities (genres). Ms Cheng, via extensive deconstruction analysis, directed the students' attention to the textual regularities of a set of key written genres, thus enabling genres to function as rhetorical shortcuts (Worden, 2018). That her teaching was better-received by the students, resulting in the students' improved writing performances, heightened genre awareness, and boosted interest and confidence in writing in an additional language, supports the previous arguments for the effectiveness of the teaching/learning circle that features in genre-based pedagogy (e.g., Chen \& Su, 2011; Ramos, 2019; Yasuda, 2011). Ms Michelle, on the other hand, integrated some processfocused activities into her other class priorities. Writing in this way, to quote Atkinson (2018), was more of "the discovery of meaning" rather than of "the achievement of correct form" (p.2). As such, Ms Michelle's approach to writing could be more appropriately characterised as "genre-informed" (Tardy et al., 2018), in which genre was still an important concept but was not uniquely, consistently, and thoroughly emphasised.

In AW, the teaching and learning of basic genres stepped down, but other important issues related to academic writing were marked with highlight and carefully taken up. Due to the nature and objective of this course, Professor Wang adopted a more 
EAP-oriented approach but still regarded arguments as a foregrounded genre in academic writing. This finding seems to suggest that, if the students learnt "how to argue" in EW I \& II, they were supposed to learn "how to argue academically and research-orientedly" in AW, as they moved forward along the academic ladder.

What strikes us most is that, with a single national syllabus to cover, the real-life teaching presented itself in the form of a pedagogical "mosaic" in which none of the approaches implemented by the focal instructors matched squarely those typically expounded upon in the L2 writing literature. Similar to the two focal instructors in Li et al. (2020) who were engaged in an ESP genre-based pedagogy in their graduate-level research writing courses, the four undergraduate-level instructors in our study demonstrated distinctive "localisation" of the various pedagogical approaches based on their understanding of the classroom realities. The ethnographic accounts given to the L2 writing instruction in the current Department enabled us to see it as a small culture (Holliday, 1999) in its own right, which was by nature delicate, dynamic, and fluid.

\section{Conclusion}

It is our humble wish that the findings from our study may yield important implications for the stakeholders in the teaching of L2 writing. First, we have provided evidences of the localisation and variability that featured in the existing practices of L2 writing instruction, which would enable the front-line practitioners may make more informed decisions and more principled choices to "localise" their approaches to suit the classroom scenarios, rather than "fossilise" their teaching behaviour by subscribing rigidly to any single approach. Second, our study also aims to send a meaningful message to policymakers and administrators aiming to offer more effective writing instruction to future Chinese EFL students. Since genre-specific writing instruction has been gaining momentum in the Chinese tertiary sector, we joined with Li et al. (2020) in suggesting that, if we are to set the genre-based pedagogy as a long-term goal to be approximated, policymakers at the national and institutional levels may consider offering professional development programme to in- and pre-service writing teachers so as to create for them some common ground for teaching, practicing, and sharing within a genrebased framework. In this regard, we argue that rich stories from the real classrooms, like those presented in this paper, will inform and enhance L2 writing teachers' training and their endeavours of continued professional development. Notwithstanding its potential contributions to the filed, our research is not without its limitations. First, for lack of accessibility, we did not include classroom observation in our ethnographic data set. This can be taken up in future research by sitting in and observing intensively how L2 writing teachers deliver their lessons, how students participate, react and learn, and how the two parties interact with each other, in the writing classrooms. In addition, due to the limited time span, our data were collected cross-sectionally from the three writing-related courses. Future studies may take the longitudinal approach to trace the students and teachers throughout the curriculum and draw a more accurate picture of their experiences in receiving and giving L2 writing instruction. Finally, our study is located in one single institution in China; we are mindful, therefore, that our findings may not be generalisable to other EFL settings where English writing is taught and learned. We hope, nevertheless, our research has put forward some methodological possibilities for 
L2 writing researchers who are interested in integrating ethnography as methodology with well-established genre theories in bringing out a context-sensitive interpretation of L2 English writing instruction and its repercussions on the student writers. The stories we presented here may serve as a point of departure for future insights from analogical settings to be compared with.

\section{Appendix A}

\section{Interview questions with the course instructors}

1. What writing objectives do you have for students in this course?

2. Do you think the concept/knowledge of genre is important for the students' development of writing capacity?

3. What genre goes first, second...etc., and why? Do you think some genres are more important, more privileged than others in the general writing courses?

4. What do you like students to be able to do in a narrative/report/argument...etc. (genres)?

5. What kinds of writing are your assignments? From where do you get them? The reasons for choosing such assignments?

6. What should students know or able to do when they write?

7. What do you look for when you evaluate their writing? What is a good narrative/ report/argument...etc.(genres) for your class? (Marking criteria)

8. What do you define as success in this course? Do you expect the students to be able to apply the genre knowledge you teach them in this course when tackling future, new, unfamiliar writing situations?

\section{Appendix B}

Interview questions with the participating students

1. What writing objectives do you have for this course? What do you expect to learn from this course?

2. Do you think the concept/knowledge of genre is important for your development of writing capacity?

3. Do you think some genres are more important/privileged/useful than others in the general writing courses?

4. What is a good narrative/report/argument...etc.(genres) in your opinion? How do you conceptualise their generic feature?

5. What do you usually do when you write for the course assignments?

6. What do you define as success in this course? Do you expect to be able to apply the genre knowledge you learn from this course when tackling future, new, unfamiliar writing situations? 


\section{Authors' contributions}

YZ: Conceptualization, Methodology, Resources, Formal Analysis, Writing-Original Draft. IP: Conceptualization, Validation, Writing — Review \& Editing, Supervision. Both authors read and approved the final manuscript.

\section{Authors' information}

Yimin Zhang holds a Ph.D. in English language studies and is now a lecturer at School of Foreign Languages, Chongqing Jiaotong University, China. Her research interests include genre analysis, academic discourse, L2 writing, and Systemic Functional Linguistics.

Issra Pramoolsook holds a Ph.D. in Applied Linguistics and English Language Teaching and is an Associate Professor at School of Foreign Languages, Institute of Social Technology, Suranaree University of Technology, Thailand. His research interests include disciplinary and professional discourses analysis, genre analysis, L2 writing, and genre-based approach to teaching writing.

\section{Funding}

This work was supported by Chongqing Municipal Education Commission, China; Grant number: 21SKGH098 and University of Chongqing Jiaotong University, China; Grant number: 2020020080.

\section{Availability of data and materials}

The datasets used and/or analysed during the current study are not publicly available due to protection for the participants' confidentiality but are available from the corresponding author upon reasonable request.

\section{Declarations}

\section{Competing interests}

The authors declare that they have no competing interests.

\section{Author details}

${ }^{1}$ School of Foreign Languages, Chongqing Jiaotong University, Chongqing, China. ${ }^{2}$ School of Foreign Languages, Institute of Social Technology, Suranaree University of Technology, 111, University Avenue, Muang, Nakhon Ratchasima 30000, Thailand.

Received: 23 September 2021 Accepted: 1 February 2022

Published online: 01 March 2022

\section{References}

Atkinson, D. (2018). Theory in second language writing. In J. I. Liontas (Ed.), The TESOL encyclopaedia of English language teaching. Wiley-Blackwell. https://doi.org/10.1002/9781118784235.eelt0524

Bacha, N. (2010). Teaching the academic argument in a university EFL environment. Journal of English for Academic Purposes, 9(3), 229-241.

Berg, M. A., \& Leonidova, O. (2021). TLC in a Russian secondary school: Writing to persuade and problem-solve. Writing and Pedagogy. https://doi.org/10.1558/wap.19543

Bhatia, V. K. (1993). Genre analysis: Theory, practice and applications. Longman.

Canagarajah, A. S. (2002). A geopolitics of academic writing. University of Pittsburgh Press.

Casanave, C. P. (2002). Writing games: Multicultural case studies of academic literacy practices in higher education. Laurence Erlbaum.

Chen, Y. S., \& Su, S. W. (2011). A genre-based approach to teaching EFL summary writing. ELT Journal, 66(2), 184-192.

Ferris, D. (2017). Facilitating L2 writers' academic language development. In J. Bitchener, N. Storch, \& R. Wette (Eds.), Teaching writing for academic purposes to multilingual students: Instructional approaches (pp. 172-195). Routledge.

Flowerdew, J. (2000). Discourse community, legitimate peripheral participation, and the non-native-English-speaker scholar. TESOL Quarterly, 34(1), 127-150.

Gao, L. (2012). Investigating ESL graduate students' intercultural experiences of academic English writing: A first person narration of a streamlined qualitative study process. The Qualitative Report, 17(12), 1-25.

Gimenez, J. (2012). Disciplinary epistemologies, generic attributes and undergraduate academic writing in nursing and midwifery. Higher Education, 63(4), 401-419.

Hasrati, M. (2013). Material and credentialing incentives as symbolic violence: Local engagement and global participation through joint publication. Journal of Business and Technical Communication, 27(2), 154-179.

Holliday, A. (1999). Small cultures. Applied Linguistics, 20(2), 237-264.

Hyland, K. (2007). Genre pedagogy: Language, literacy and L2 writing instruction. Journal of Second Language Writing, 16(3), 148-164.

Leki, I., \& Carson, J. (1997). 'Completely different worlds': EAP and the writing experiences of ESL students in university courses. TESOL Quarterly, 37(1), 39-69.

Li, Y., Ma, X., Zhao, J., \& Hu, J. (2020). Graduate-level research writing instruction: Two Chinese EAP teachers'localized ESP genre-based pedagogy. Journal of English for Academic Purposes, 43, 100813. https://doi.org/10.1016/j.jeap.2019. 100813

Liardét, C. L. (2018). 'As we all know': Examining Chinese EFL learners' use of interpersonal grammatical metaphor in academic writing. English for Specific Purposes, 50, 64-80.

Lillis, T. (2008). Ethnography as method, methodology, and 'deep theorizing': Closing the gap between text and context in academic writing research. Written Communication, 25(3), 353-388. 
Lillis, T., \& Curry, M. J. (2010). Academic writing in a global context: The politics and practices of publishing in English. Routledge.

Liu, Y. (2015). The effects of group peer feedback and teacher feedback in teaching writing to English majors. Foreign Language World, 166(1), 48-55.

Luke, A., \& Freebody, P. (1997). Shaping the social practices of reading. In S. Muspratt, A. Luke, \& P. Freebody (Eds.), Constructing critical literacies: Teaching and learning textual practice (pp. 185-225). Allen \& Unwin.

$\mathrm{Ma}$, G. (2009). Lexical bundles in L2 English majors'timed writing. Foreign Language Teaching and Research, 41(1), 54-60.

Martin, J. R., \& Rose, D. (2005). Designing literacy pedagogy: Scaffolding asymmetries. In J. Webster, C. Matthiessen, \& R. Hasan (Eds.), Continuing discourse on language (pp. 251-280). Continuum.

Martin, J. R., \& Rose, D. (2007). Interacting with text: The role of dialogue in learning to read and write. Foreign Languages in China, 4(5), 66-80.

Martin, J. R., \& Rose, D. (2008). Genre relations: Mapping culture. Equinox.

Matsuda, P. K. (2003). Second language writing in the twentieth century: A situated historical perspective. In B. Kroll (Ed.), Exploring the dynamics of second language writing (pp. 15-34). Cambridge University Press.

Maxwell, J. A. (2005). Qualitative research design: An interactive approach (2nd ed.). Sage.

Paltridge, B. (2007). Beyond the text: A textography of Chinese College English writing. University of Sydney Papers in TESOL, 2(2), 149-165.

Paltridge, B., \& Woodrow, L. (2012). Thesis and dissertation writing: Moving beyond the text. In R. Tang (Ed.), Academic writing in a second or foreign language: Issues and challenges facing ESL/EFL academic writers in higher education contexts (pp. 88-104). Continuum.

Paltridge, B., Starfield, S., \& Tardy, C. M. (2016). Ethnographic perspectives on academic writing. Oxford University Press.

Qi, Y. (2004). The effects of feedback in teaching English writing: In argumentative writing of English majors. Foreign Language Teaching Abroad, 1, 47-53.

Ramos, K. (2019). A genre-based approach to teaching argument writing. In L. C. de Oliveira, K. M. Obenchain, R. H. Kenney, \& A. W. Oliveira (Eds.), Teaching the content areas to English language learners in secondary schools (pp. 49-63) Berlin: Springer.

Rose, D. (2010). Genre in the Sydney School. In J. P. Gee \& M. Handford (Eds.), The Routledge handbook of discourse analysis (pp. 209-225). Routledge.

Rothery, J., \& Stenglin, M. (1994). Writing a book review: A unit of work for junior secondary English (Write it Right Resources for Literacy and Learning). Metropolitan East Disadvantaged Schools Program.

Sarangi, S. (2006). The conditions and consequences of professional discourse studies. In R. Kiely, P. Rea-Dickins, H. Woodfield, \& G. Clibbon (Eds.), Language, culture and identity in applied linguistics (pp. 199-220). Equinox.

Sasaki, M. (2000). Toward an empirical model of EFL writing processes: An exploratory study. Journal of Second Language Writing, 9(3), 259-291.

Starfield, S. (2004). Word power: Negotiating success in a first-year sociology essay. In L. Ravelli \& R. A. Ellis (Eds.), Analysing academic writing: Contextualised frameworks. Continuum.

Swales, J. M. (2004). Research genres: Explorations and applications. Cambridge University Press.

Tardy, C. M. (2009). Building genre knowledge. Parlor Press.

Tardy, C. M. (2015). Bending genres, or when is a deviation an innovation? In N. Artemeva \& A. Freedman (Eds.), Genre studies around the world: Beyond the three traditions (pp. 303-322). Inkshed Publications.

Tardy, C. M., Buck, R. H., Pawlowski, M., \& Slinkard, J. R. (2018). Evolving Conceptions of Genre among First-Year Writing Teachers. In Composition Forum (Vol. 38). Association of Teachers of Advanced Composition. Retrieved from http:// compositionforum.com/issue/38/evolving.php.

Teaching Advisory Committee for Tertiary English Majors. (2000). English Teaching Syllabus for English Majors. Foreign Language Teaching and Researching Press.

Tribble, C. (2002). Corpora and corpus analysis: New windows on academic writing. In J. Flowerdew (Ed.), Academic discourse (pp. 131-149). Routledge.

Wang, X. (2010). TP pattern and coherence in English writing: Analysis of TEM-4 writing papers. Foreign Language Research, 153(2), 103-106.

Worden, D. (2018). Balancing stability and flexibility in genre-based writing instruction: A case study of a novice L2 writing teacher. Journal of Second Language Writing, 42, 44-57.

$X u, F$. (2010). Retrieving patterns of lexical sequences in L2 English majors'timed writing. Foreign Languages and Their Teaching, 250(1), 22-26.

Yasuda, S. (2011). Genre-based tasks in foreign language writing: Developing writers' genre awareness, linguistic knowledge, and writing competence. Journal of Second Language Writing, 20(2), 111-133.

Zamel, V. (1983). The composing processes of advanced ESL students: Six case studies. TESOL Quarterly, 17(2), 165-188.

Zhang, Y., \& Pramoolsook, I. (2020). Beyond the argument: Generic diversity in instruction-based writing by Chinese EFL undergraduate students. Asian EFL Journal, 24(3), 123-160.

\section{Publisher's Note}

Springer Nature remains neutral with regard to jurisdictional claims in published maps and institutional affiliations. 